УДК 338.27

\title{
НЕОБХІДНІСТЬ ПРОГНОЗУВАННЯ РІВНЯ ЕКОНОМІЧНОЇ БЕЗПЕКИ ЯК АНТИКРИЗОВОГО ІНСТРУМЕНТУ В ПУБЛІЧНОМУ УПРАВЛІННІ
}

\section{A NECESSITY OF ECONOMIC SECURITY FORECAST AS AN ANTI-CRISIS INSTRUMENT IN A PUBLIC GOVERNANCE}

\author{
Максимова Марина Валеріївна \\ кандидат економічних наук, \\ Харківський національний університет імені В.Н. Каразіна \\ ORCID: https://orcid.org/0000-0002-0697-2906 \\ Сукрушева Ганна Олегівна \\ кандидат економічних наук, доцент, \\ Харківський національний університет імені В.Н. Каразіна \\ ORCID: https://orcid.org/0000-0003-2497-9332 \\ Maksimova Maryna, Sukursheva Hanna \\ V.N. Karazin Kharkiv National University
}

Стаття присвячена необхідності прогнозування рівня економічної безпеки як антикризового інструменту у публічному управлінні. Рівень економічної безпеки регіону, залежить від значного числа загроз і ризиків внутрішнього і зовнішнього середовища, які представляють найбільшу небезпеку для стратегічного розвитку регіону в умовах мінливої кон'юктури ринку. Ефективна система економічної безпеки регіону є інтеграцію двох складових - забезпечення результативності комплексу заходів для ії̈ досягнення і здібності своєчасного реагування на виявлені загрози від зовнішнього і внутрішнього середовища. Тому найважливіша роль відведена прогнозуванню соціально-економічних показників, що виступають індикаторами економічної безпеки регіону, що дозволяє оперативно здійснювати кількісну і якісну оцінку ризиків, забезпечувати фрункціональну стійкість розвитку, а також реагувати на зміни. Питання забезпечення економічної безпеки регіону, в умовах хаотичного виникнення внутрішніх і зовнішніх загроз визначають можливість досягнення сталого розвитку.

Ключові слова: регіон, безпека, антикризові заходи, публічне управління, прогнозування, соціальноекономічний розвиток.

Статья посвящена необходимости прогнозирования уровня экономической безопасности как антикризисного инструмента в государственном управлении. Уровень экономической безопасности региона, зависит от значительного числа угроз и рисков внутренней и внешней среды, представляющих наибольшую опасность для стратегического развития региона в условиях меняющейся рыночной конъюнктуры. Эфрфективная система экономической безопасности региона заключается в интеграции двух компонентов - обеспечение эффрективности набора мер для его достижения и способности реагировать на обнаруженные угрозы из внешних и внутренних сред. Поэтому наиболее важная роль отдается предсказанию социально-экономических показателей, которые являются индикаторами экономической безопасности региона, что позволяет оперативно реализовать количественную и качественную оценку риска, чтобы обеспечить фрунциональное развитие, а также реагировать на изменения. Вопрос обеспечения экономической безопасности региона, в условиях хаотичного возникновения внутренних и внешних угроз, определяют возможность достижения устойчивого развития региона.

Ключевые слова: регион, безопасность, антикризисные мероприятия, государственное управление, прогнозирование, социально-экономическое развитие.

A necessity of economic security forecast as an anti-crisis instrument in a public governance is devoted in the article. The problem of forming an effective system of economic security indicators is related to the necessity of improving the regions' economic condition. The level of the region economic security depends on threats and risks of the internal and external environment, which present the greatest threat to the strategic development of the region in a changing market environment. The effective system of the region economic security combines two 
components - ensuring the effectiveness of a complex measures to achieve it and the ability to respond in a timely manner to identify threats from the external and internal environment. Therefore, the most important role is given to forecasting socio-economic indicators of the region economic security, which allow carrying out quantitative and qualitative risk assessment quickly, ensure functional sustainability, and respond to changes. Issues of ensuring the region economic security in the chaotic emergence of internal and external threats determine the possibility of achieving sustainable development. To reduce the impact of threats and eliminate them, each region must create its own, individual mechanism-indicator of the state of economic security, able to monitor the threat at the current level. However, the complex of threats depends on region specific qualities, use different methods of analysis, forecasting and ranking of threats in order to identify and prevent the most dangerous at this stage. The issue of forecasting the state of economic security is a very important aspect in building anti-crisis measures in public governance, and this requires both practical and theoretical research in this area. Not all indicators can be used for assessment of the state region economic security, but only those that most closely meet the specifics of the region, the objectives of crisis management, and best reflect the results of socio-economic development and, ideally, do not contradict each other. A necessity of improving the forecast system of a region socio-economic situation is the important task for increasing efficiency of a public governance.

Keywords: region, security, anti-crisis instrument, public governance, forecasting, socio-economic development.

Постановка проблеми. Для формування стратегічних планів соціально-економічного розвитку регіонів необхідно об'єктивне обґрунтування фракторів, в тому числі з використанням методів прогнозування соціальноекономічних показників, виявлення кореляції між ними, моделювання окремих напрямків. Для цих завдань може застосовуватися i методологія економічної безпеки регіону. Тим більше що стратегічне планування - це діяльність, спрямована в тому числі на забезпечення національної безпеки України, елементом якої $є$ економічна безпека регіону.

Аналіз останніх досліджень і публікацій. Питаннями прогнозування соціальноекономічного розвитку на рівні регіону, присвячені роботи таких вчених як: Р. Білик, В. Геєць, М. Кизим, Т. Клебанова, О. Черняк, А. Гуменюк, С. Онищенко, В. Предборський, Я. Пушак, Я. Піцура, О. Солодовнік, В. Федоренко, І. Грищенко. Їхні праці $є$ базою для удосконалення існуючих методик прогнозування соціально-економічного розвитку регіонів. Оскільки, при постійних змінах економічного середовища, $€$ необхідність удосконалюватися методики антикризового управління на рівні регіонів, впровадження нових способів прогнозування соціально-економічного розвитку для фрормування оптимальної системи управління регіональним розвитком.

Виділення невирішених раніше частин загальної проблеми. Особливий інтерес представляє розробка системи прогнозування основних соціально-економічних показників, що впливають на економічну безпеку регіону. Проте на сьогодні, відсутній чіткий підхід до створення механізму прогнозування економічної безпеки на регіональному рівні, не визначено мінімальний інформативний набір індикаторів, їх порогові значення, не вирішені методичні питання організації прогнозування задля прийняття ефективних рішень стосовно запобігання загроз економічній безпеці.

Формулювання цілей статті (постановка завдання). В роботі представлено прогнозування соціально-економічних показників, що впливають на рівень економічної безпеки Харківської області.

Виклад основного матеріалу дослідження. Антикризове управління регіоном, потребує проведення глибокого і всебічного моніторингу фрункціонування територіальної системи. Схильність відкритих соціальноекономічних систем до зовнішніх впливів і впливу внутрішніх дестабілізуючих чинників означає виникнення різних за ступенем керованості ризиків і загроз економічній безпеці. Економічна безпека регіону ґрунтується на здатності ссрер і елементів системи фрункціонувати при дотриманні вимоги забезпечення допустимих ризиків, зберігати стійкість під впливом погроз і негативного впливу сукупності фракторів. Найбільш важливими і контрольованими сорерами економічної безпеки території $€$ : якість життя населення, виробнича i фрінансова складові, бюджет і інсрраструктура, інвестиційний потенціал. Результати прогнозування найважливіших показників розвитку соціально-економічної ссрери території і рівня її економічної безпеки, отримані 3 використанням пропонованого авторами інструменту, дозволяють оцінити наслідки прийнятих управлінських рішень і ризики їх реалізації як відгук системи на дію сукупності керованих і некерованих фракторів [6, с. 43]. Умови невизначеності та підвищеного ризику з боку політичних, економічних, військових та інших фракторів вимагають від органів державної влади ефективного застосування методів антикризового планування 
соціально-економічного розвитку держави та окремих його територіальних одиниць. Забезпечення умов для створення керованого процесу мінімізації негативних наслідків дії ризиків і забезпечення високого рівня економічної безпеки $є$ складною методологічною (з точки зору розробки і реалізації апарату застосовуваних методів та інструментів) і прикладною задачею [2, с. 43].

Увага органів управління зосереджено на пошуку ефективних інструментів регулювання і контролю соціальних і економічних викликів і загроз, ризиків і дестабілізуючих систему чинників. Оцінка ймовірності впливу зовнішніх і внутрішніх процесів і явищ, масштабів їх впливу на параметри соціально-економічної динаміки регіонів лежить в основі розробки прогнозів територій.

Успішність фрункціонування економіки регіону, його стійкість і економічна безпека строго і безпосередньо залежать від якості побудови прогнозних документів та адекватності прийнятих управлінських рішень. Вченими і практиками в області державного управління розроблено значну кількість підходів, запропонований ряд інструментів, спрямованих на оцінку вірогідності показників і індикаторів розвитку територій [3, с. 268].

При прогнозуванні показників соціальноекономічного розвитку території та рівня її економічної безпеки передбачається, що зберігаються основні параметри і умови національної та регіональної систем: зовнішні і внутрішні фрактори ризику, які впливають на соціальноекономічні процеси, що протікають на території регіону; реалізуються заплановані програми і ресорми, згідно з основними індикаторами регламентують їх актів і документів; відтворювальний процес протікає в рамках планова- ного органами влади економічного циклу; раціонально розподіляється вироблений продукт і дохід. При такому стратегічному плануванні не враховується набір фракторів, що породжуються нестабільністю економічного та політичного середовища, поведінкою економічних суб'єктів, що змінюється соціальної обстановкою і інші [7, с. 112]. Процес ідентифрікації та аналізу ризиків в рамках прогнозування розвитку соціально-економічної системи мезорівня $\epsilon$ основою процедури оцінки ризику прийняття рішень органами управління. В роботі буде проведено прогнозування безпеки Харківської області на основі економічних, соціальних та фрінансових показників з використанням лінійного тренду. Та виявлення тенденції покращення чи погіршення безпеки Харківського регіону. В таблиці 1 наведено вихідні дані для прогнозування економічних показників Харківської області.

В таблиці 2 наведено результати прогнозування за економічними показниками.

За проведеними розрахунками, можна визначити, що за всіма економічними показниками, крім зносу основних фрондів та середнього показнику сільськогосподарської продукції можливо побачити тенденцію до зростання. За розрахунками, повинен припинитися та почати зменшуватися знос основних фрондів, що $€$ позитивною тенденцією розвитку Харківської області. Стосовно показника сільськогосподарської продукції на душу населення, можна сказати, що Харківська області, не відноситься до аграрних областей України, і перше завдання яке перед нею стоїть - це розвиток промислового комплексу.

В таблиці 4 представлено розрахунок прогнозних обсягів соціальних показників Харківської області.

Вихідні дані для прогнозування економічних показників Харківської області

\begin{tabular}{|l|c|c|c|c|c|}
\hline \multicolumn{1}{|c|}{ Показник } & \multicolumn{5}{|c|}{ Значення } \\
\cline { 2 - 7 } & $\mathbf{2 0 1 5}$ рік & $\mathbf{2 0 1 6}$ рік & $\mathbf{2 0 1 7}$ рік & $\mathbf{2 0 1 8}$ рік & $\mathbf{2 0 1 9}$ рік \\
\hline $\begin{array}{l}\text { Валовий регіональний продукт на душу } \\
\text { населення, грн. }\end{array}$ & 45815 & 57669 & 69907 & 87700 & 93687 \\
\hline $\begin{array}{l}\text { Середній показник обсягу промислового } \\
\text { виробництва на душу населення, грн. }\end{array}$ & 41929 & 57221 & 68960 & 82872 & 81739 \\
\hline $\begin{array}{l}\text { Середній показник сільськогосподарської } \\
\text { продукції на душу населення, грн. }\end{array}$ & 4468 & 5621 & 6754 & 7617 & 7596 \\
\hline Ступень зносу основних фондів, \% & 75,3 & 75,8 & 76,4 & 78,2 & 81,7 \\
\hline $\begin{array}{l}\text { Середній показник обороту роздрібної } \\
\text { торгівлі на душу населення, грн. }\end{array}$ & 30439 & 35669 & 24228 & 27117 & 31018 \\
\hline Індекс споживчих цін, \% & 144,2 & 114,1 & 113,8 & 111,2 & 104,8 \\
\hline
\end{tabular}


Таблиця 2

Результати прогнозування за економічними показниками

\begin{tabular}{|l|c|c|c|}
\hline \multicolumn{1}{|c|}{ Показник } & \multicolumn{3}{|c|}{ Прогнозне значення } \\
\cline { 2 - 4 } & $\mathbf{2 0 2 0}$ рік & $\mathbf{2 0 2 1}$ рік & $\mathbf{2 0 2 2}$ рік \\
\hline $\begin{array}{l}\text { Валовий регіональний продукт на душу } \\
\text { населення, грн. }\end{array}$ & 108691 & 121269 & 133847 \\
\hline $\begin{array}{l}\text { Середній показник обсягу промислового } \\
\text { виробництва на душу населення, грн. }\end{array}$ & 98125 & 108652 & 119179 \\
\hline $\begin{array}{l}\text { Середній показник сільськогосподарської } \\
\text { продукції на душу населення, грн. }\end{array}$ & 27476 & 26736 & 25997 \\
\hline Ступень зносу основних фрондів, \% & 93,1 & 84,9 & 76,8 \\
\hline $\begin{array}{l}\text { Середній показник обороту роздрібної } \\
\text { торгівлі на душу населення, грн. }\end{array}$ & 8887 & 9712 & 10537 \\
\hline
\end{tabular}

Джерело: складено автором

Таблиця 3

Вихідні дані для прогнозування соціальних показників Харківської області

\begin{tabular}{|l|c|c|c|c|c|}
\hline \multicolumn{1}{|c|}{ Показник } & \multicolumn{5}{c|}{ Значення } \\
\cline { 2 - 6 } & $\mathbf{2 0 1 5}$ рік & $\mathbf{2 0 1 6}$ рік & $\mathbf{2 0 1 7}$ рік & $\mathbf{2 0 1 8}$ рік & $\mathbf{2 0 1 9}$ рік \\
\hline Середня чисельність населення, тис. осіб & 2724,9 & 2685,5 & 2678,4 & 2660,0 & 2642,8 \\
\hline $\begin{array}{l}\text { Коесріцієнт природного приросту населення, } \\
\text { на 1 тис. осіб }\end{array}$ & $-6,4$ & $-6,7$ & $-7,2$ & $-8,6$ & $-8,4$ \\
\hline $\begin{array}{l}\text { Очікувана тривалість життя при народженні, } \\
\text { роки }\end{array}$ & 71,15 & 71,46 & 71,88 & 71,4 & 71,84 \\
\hline Рівень безробіття, \% & 7,1 & 6,4 & 6,1 & 5,3 & 5,0 \\
\hline Реальні доходи населення, млн. грн. & 113952 & 132641 & 175850 & 216227 & 246086 \\
\hline $\begin{array}{l}\text { Середньодушові грошові доходи населення, } \\
\text { грн. на місяць }\end{array}$ & 2683,2 & 3183,1 & 4030,8 & 4701,7 & 5545,6 \\
\hline $\begin{array}{l}\text { Чисельність населення з грошовими доходами } \\
\text { нижче величини прожиткового мінімуму, } \\
\text { \% від загальної чисельності населення }\end{array}$ & 60,1 & 58,9 & 34,4 & 32,1 & 26,0 \\
\hline Число злочинів на 100 тис. осіб, одиниць & 19,8 & 19,0 & 12,3 & 11,4 & 8,95 \\
\hline
\end{tabular}

Джерело: складено автором на основі [5]

Таблиця 4

Результати прогнозування за соціальними показниками

\begin{tabular}{|l|c|c|c|}
\hline \multicolumn{1}{|c|}{ Показник } & \multicolumn{3}{c|}{ Прогнозне значення } \\
\cline { 2 - 4 } & $\mathbf{2 0 2 0}$ рік & $\mathbf{2 0 2 1}$ рік & $\mathbf{2 0 2 2}$ рік \\
\hline Середня чисельність населення, тис. осіб & 2621,4 & 2602,4 & 2583,4 \\
\hline $\begin{array}{l}\text { Коедріцієнт природного приросту населення, } \\
\text { на 1 тис. осіб }\end{array}$ & $-9,2$ & $-9,8$ & $-10,4$ \\
\hline Очікувана тривалість життя при народженні, роки & 71,9 & 72,04 & 72,2 \\
\hline Рівень безробіття, \% & 3,9 & 3,3 & 2,7 \\
\hline Реальні доходи населення, млрд. грн. & 13,8 & 16,4 & 18,5 \\
\hline $\begin{array}{l}\text { Середньодушові грошові доходи населення, } \\
\text { грн. на місяць }\end{array}$ & 6202 & 6926 & 7650 \\
\hline $\begin{array}{l}\text { Чисельність населення з грошовими доходами } \\
\text { нижче величини прожиткового мінімуму, \% від } \\
\text { загальної чисельності населення }\end{array}$ & 35,07 & 20,92 & 6,12 \\
\hline Число злочинів на 100 тис. осіб, одиниць & 13,4 & 10,8 & 8,2 \\
\hline
\end{tabular}


За результатами розрахунку таблиці 4, можна визначити, що соціальні показники в період 32020 по 2022 роки, будуть розвиватися неоднозначно, так можна очікувати збільшення реальних доходів населення, середньодушових доходів населення в розрахунку на місяць, невелике збільшення можна прослідкувати за показником - Очікувана тривалість життя при народженні. Однак, чисельність населення в Харківській області буде зменшуватися, і в свою чергу буде збільшуватися коефіцієнт природного зменшення населення. Необхідно відмітити, що повинен зменшуватися коефіцієнт безробіття, кількість злочинів, та що важливо це показник чисельності населення 3 грошовими доходами нижчими величини прожиткового мінімуму, що є позитивною тенденцією в розвитку соціально-економічного стану Харківської області. В таблиці 5 представлено дані для побудови лінії тренду за фрінансовими показниками.

В таблиці 6 представлено розрахунок прогнозних обсягів фрінансових показників Харківської області.

За розрахунками, що наведено в таблиці 6, можна сказати, що фрінансові показники в Харківській області мають тенденцію до зростання, що є позитивним фрактором в розвитку Харківського регіону.

Таким чином, можна зробити висновок, в останні час зростає самостійність територій, які несуть все більш серйозну відповідаль- ність за підсумки свого антикризового управління. Однак, державі необхідно постійно проводити ефрективні антикризові програми, підтримувати регіони, щоб уникнути в них кризового стану. Соціально-економічне становище областей України, можна пояснити, як об'єктивними причинами (галузева структура, макроекономічні ситуація, природні ресурси, демограсрічні умови), так і суб'єктивними причинами, і перш за все - методами управління територією [1, с. 156].

В останні роки проведення економічних реформ показало, що регіони, які використовують прогресивні підходи до управління розвитком територій, в найменшій мірі піддаються кризовим тенденціям. В непростихумовах, в період подолання кризи, порівняльну перевагу мали, насамперед, ті території, які застосовували адекватні сучасні інструменти і методи управління власним розвитком. Регулювання територіального розвитку може здійснюватися при використанні широкого спектра певних дій, за допомогою яких держава стимулює розвиток економіки конкретного суб'єкта, збільшує податкову базу, створює додаткові робочі місця, розширює потенціал для тих видів економічної активності, в якому у даного регіону найбільшу кількість можливостей.

Парадигма сталого розвитку, що передбачає динамічний процес послідовних позитивних змін, які забезпечують збалансованість економічного, соціального та фрінансових

Таблиця 5

Вихідні дані для прогнозування фрінансових показників Харківської області

\begin{tabular}{|l|c|c|c|c|c|}
\hline \multicolumn{2}{|c|}{ Показник } & \multicolumn{5}{|c|}{ Значення } \\
\cline { 2 - 7 } & $\mathbf{2 0 1 5}$ рік & $\mathbf{2 0 1 6}$ рік & $\mathbf{2 0 1 7}$ рік & $\mathbf{2 0 1 8}$ рік & $\mathbf{2 0 1 9}$ рік \\
\hline Інвестиції в основний капітал, у \% до ВРП & 9,0 & 10,7 & 10,3 & 10,1 & 9,2 \\
\hline Капітальні інвестиції на одну особу, грн. & 4151,1 & 6141,1 & 7219,2 & 8823,5 & 9268,4 \\
\hline Питома вага збиткових організацій, \% & 40,0 & 30,3 & 27,1 & 20,1 & 28,1 \\
\hline $\begin{array}{l}\text { Доходи бюджету Харківської області, } \\
\text { на душу населення, грн. }\end{array}$ & 9974 & 11604 & 11635 & 13637 & 17859 \\
\hline
\end{tabular}

Джерело: складено автором на основі [5]

Таблиця 6

Результати прогнозування за фрінансовими показниками

\begin{tabular}{|l|c|c|c|}
\hline \multirow{2}{*}{ Показник } & \multicolumn{3}{|c|}{ Прогнозне значення } \\
\cline { 2 - 4 } & $\mathbf{2 0 2 0}$ рік & $\mathbf{2 0 2 1}$ рік & $\mathbf{2 0 2 2}$ рік \\
\hline Інвестиції в основний капітал, у \% до ВРП & 9,8 & 9,9 & 10,0 \\
\hline Капітальні інвестиції на одну особу, грн. & 10996 & 12287,5 & 13579,2 \\
\hline Питома вага збиткових організацій, \% & 18,9 & 15,5 & 12,1 \\
\hline $\begin{array}{l}\text { Доходи бюджету Харківської області, } \\
\text { на душу населення, грн. }\end{array}$ & 18283 & 20063 & 21843 \\
\hline
\end{tabular}


аспектів, повинна лежати в основі фрормування підходів до вирішення проблем територіальних утворень. Це особливо актуально сьогодні, коли відбувається перенесення центру ваги економічних рефрорм на рівень регіонів і посилення їх ролі в реалізації економічної політики держави. Кризова ситуація соціально-економічного розвитку території буде виражатися в зниженні: прибутків організацій, якості життя населення, доходів бюджету, ВРП і інших показників. Це в свою чергу призведе до скорочення робочих місць і тривалої кризи. В даний час антикризове управління на територіях України має бути направлено на розробку державних регіональних антикризових програм. Економічна політика і соціальний розвиток нерозривно пов'язані між собою, оскільки фрінансування соціальної сфрери безпосередньо залежить від економічного потенціалу територіальних утворень України. Стратегії теоретичних і практичних проблем орормування територіальних антикризових програм, незважаючи на їхню соціальну значимість, розроблені недостатньо і стосуються, в основному, окремих аспектів цієї проблеми.

Саме тому управління антикризовим розвитком, фрормуючи, з одного боку, першорядні завдання і цілі власного розвитку на визначеному часовому етапі, з іншого боку, стає основою для формування в своєму складі рівних стратегій економічного і соціального розвитку регіонів. Природно, що підхіддержавногоантикризового територіального управління змінюється в залежності від геополітичної і соціально-економічної спрямованості держави на певному рубежі розвитку, створених відносин між центральними та місцевими органами влади, зовнішньоекономічних умов, тобто від системи чинників і критеріїв, що впливають на цільові пріоритети розвитку суспільства. Такі підходи можна втілити в антикризових оперативних діях і державних програмах, які допомагають розвитку суб'єктів, населених пунктів і міст в ефективному напрямку. У будь-якій сорері життя територіального об'єднання, подолання кризи пов'язане зі ступенем економічної, та фрінансової активності. Соціальноекономічний розвиток значною мірою обумовлюється ресурсним потенціалом, який, в свою чергу, залежить від рівня розвитку окремої території. Тому, розвиваючи соціально-економічну інтенсивність, можна реалізувати ті чи інші завдання в житті Харківської області, підвищити рівень добробуту населення, який, в кінцевому підсумку, завжди показує ступінь ефрективності тієї чи іншої державної антикризової політики управління територіями.

Висновки. Державна територіальна політика антикризового управління сконцентрована на забезпеченості стабільного соціально-економічного розвитку територій України, а саме забезпечення його економічної безпеки. А також на зниження ступеня міжрегіональної диореренціації в соціальноекономічному становищі окремих територіальних утворень і якості їх життя. В якості кінцевого результату даного завдання в процесі реалізації державної антикризової політики, націленої на ефективну реалізацію можливостей розвитку окремої області, буде забезпечено створення однакових можливостей громадян, сприяння розвитку людського потенціалу, перетворення систем державного управління та місцевого самоврядування, а також здійснення цілеспрямованої діяльності з формування якісного антикризового управління.

\section{СПИСОК ВИКОРИСТАНИХ ДЖЕРЕЛ:}

1. Білик Р.Р. Детермінанти регіонального розвитку у вимірі економічної безпеки України : монограсрія. Львів : НАН України. ДУ «Інститут регіональних досліджень імені М.І. Долішнього НАН України», 2016. 352 с.

2. Геєць В.М., Кизим М.О., Клебанова Т.С., Черняк О.І. Моделювання економічної безпеки : монографрія Харків : ІНЖЕК, 2006. 240 c.

3. Гуменюк А.М. Безпека структурно-інституціональної транссормації економіки регіону: теоретичні основи та прикладні аспекти : монографрія. Київ : НІСД, 2014. 468 с.

4. Онищенко С.В. Економічна безпека: держава, регіон, підприємство : монографрія. Полтава : ПолтНТУ, 2019. 389 c.

5. Офріційний сайт Державної служби статистики України. Збірник «Україна у цифррах, 2020». URL: http://ukrstat.gov.ua/druk/publicat/kat_u/2021/zb/07/zb

6. Пушак Я.Я., Піцура Я.С. Актуальні проблеми забезпечення економічної безпеки в Україні : колективна монографія. Львів : Ліга-Прес, 2017. 368 с.

7. Солодовнік О.О. Основні підходи до оцінювання економічної та фінансової безпеки: сутність і напрями вдосконалення. Бізнес Інфоорм. 2021. № 2. C. 6-12. DOI: https://doi.org/10.32983/2222-4459-2021-2-6-12 


\section{REFERENCES:}

1. Bilyk P.P. (2016) Determinanty rehionalnoho rozvytku u vymiri ekonomichnoi bezpeky Ukrainy: monohrafiia [Determinants of regional development in the economic dimension Security of Ukraine: monograph]. Lviv: NAN Ukrainy. DU «Instytut rehionalnykh doslidzhen imeni M.I. Dolishnoho NAN Ukrainy», 352 p. (in Ukrainian)

2. Heiets V.M., Kyzym M.O., Klebanova T.S., Cherniak O.I. (2006) Modeliuvannia ekonomichnoi bezpeky: monohrafiia [Modeling of Economic Security: monograph]. Kharkiv: INZhEK, 240 p. (in Ukrainian)

3. Humeniuk A.M. (2014) Bezpeka strukturno-instytutsionalnoi transformatsii ekonomiky rehionu: teoretychni osnovy ta prykladni aspekty: monohrafiia [Security of structural and institutional transformation of the region's economy: Theoretical bases and applied aspects: monograph]. Kyiv: NISD, 468 p. (in Ukrainian)

4. Onyshchenko S.V. (2019) Ekonomichna bezpeka: derzhava, rehion, pidpryiemstvo: monohrafiia [Economic Security: State, Region, Enterprise: monograph]. Poltava: PoltNTU, 389 p. (in Ukrainian)

5. Ofitsiinyi sait Derzhavnoi sluzhby statystyky Ukrainy. Zbirnyk «Ukraina u tsyfrakh, 2020». Available at: http://ukrstat.gov.ua/druk/publicat/kat_u/2021/zb/07/zb

6. Pushak Ya.la., Pitsura Ya.S. (2017) Aktualni problemy zabezpechennia ekonomichnoi bezpeky v Ukraini: kolektyvna monohrafiia [Actual problems of economic security in Ukraine: collective monograph]. Lviv: Liha-Pres, 368 p. (in Ukrainian)

7. Fedorenko V.H., Hryshchenko I.M. ta in. (2017) Ekonomichna bezpeka Ukrainy: monohrafiia [Economic Security of Ukraine: monograph]. Kyiv: TOV «DKS tsentr», 462 p. (in Ukrainian) 